Insight, part of a Special Feature on Exploring Social-Ecological Resilience through the Lens of the Social Sciences: Contributions. Critical Reflections, and Constructive Debate

\title{
Making social sense of aquaculture transitions
}

\author{
Simon R. Bush ${ }^{1}$ and Melissa J. Marschke ${ }^{2}$
}

\begin{abstract}
Resilience deals explicitly with change and provides a middle ground between the social and the environmental sciences. However, a growing critique by social scientists questions the ability of resilience thinking to adequately examine the social dimensions of change. The question that emerges is how social scientists should engage with resilience. We addressed this question by comparing resilience with agrarian change and transitions theory, through the backdrop of the fastest growing global food sector, aquaculture. Our analysis showed that each theoretical perspective provides fundamentally different insights into social and environmental transition inherent in the aquaculture sector. Although resilience thinking is best suited to assessing the ecological aspects of production, its systems ontology limits the inclusion of dynamic social relations or innovation. In contrast, agrarian transition enables a more meaningful understanding of how social relations are reconfigured as agrarian society shifts toward more capitalist modes of production, and transitions theory provides insights into social process of innovation. Given the epistemological differences between these theoretical approaches, we argue against attempts that reify systemic thinking by naturalizing social theories and concepts into resilience thinking. Instead, we argue that social theories such as agrarian change and transition theory should be seen as complimentary and that integration should focus on bridging results and insights. Doing so enables a more robust assessment of the social aspects of social-ecological transitions in the aquaculture sector and beyond.
\end{abstract}

Key Words: agrarian change; aquaculture; Asia; resilience; social change; transition theory

\section{INTRODUCTION}

The emergence and rapid expansion of resilience thinking, based largely on the new ecology of growth, decay, and renewal between multiple equilibriums (e.g., Holling 2001, Gunderson and Holling 2002), has been met with cautious interest by social scientists. Despite Adger's (2000) early agenda for exploring the links between social and ecological resilience, a clear delineation has remained problematic. Critics highlight the epistemological divide between the natural and social sciences, which hampers exchange and collaboration (Miller et al. 2010). From a social scientist's perspective, this divide is underlined by the absence of fundamental social questions of power and politics, such as resilience by whom and for whom (e.g., Nadasdy 2007, BeymerFarris et al. 2012, Davoudi 2012). Critics argue that without recognizing the forces that define choice, panarchy and adaptive governance remain prescriptive, deterministic, and unable to elaborate social processes of change (Davidson 2010, Cote and Nightingale 2012). Others have argued that resilience thinking fails to adequately take into account human agency and suffering (Turner 2013), as well as social processes of innovation (Moore et al. 2012).

However, resilience is acknowledged, even by its critics (e.g., Cote and Nightingale 2012), as providing a strong middle ground between the social and environmental sciences. As Brown (2013) argues, the malleability of the term adds to the strength of resilience as a cohesive discourse in both science and policy. Resilience as a body of thinking deals explicitly with change, which is important given the rate, scale, and magnitude of environmental change we face globally (O'Brien 2012). The question remaining is how social scientists should engage with resilience. Understanding this question requires taking stock of what resilience thinking can offer social scientists, while also considering other approaches that investigate and theorize about social and environmental change. What do these approaches offer that resilience-based, social-ecological analyses do not offer, or offer only weakly? If we understand these other approaches as complementary, should they be integrated into resilience thinking, or given the epistemological differences between resilience and other social science theories (Miller et al. 2010), remain as corresponding forms of analysis?

We address these questions by assessing how two alternative bodies of social science literature, agrarian change and sociotechnical transitional theory, deal with the social aspects of environmental change. These two approaches address change from two distinct social science perspectives, posing fundamentally different questions to the ecologically derived notion of resilience. Agrarian change focuses on the transition pathways by which agrarian society shifts toward a capitalist mode of production, and how social relations that compose the agrarian class are reconfigured through such a transition (cf., Scott 1985, Hart 1989, Li 1999, Rigg 2001, Rigg and Vandergeest 2012). So-called transition theory defines socio-technical pathways of change through systemic innovation (Geels 2002, Grin et al. 2010). Like resilience thinking, it is a based on notions of multiple nested scales, is prescriptive in nature, and focuses on normative processes of transition management (Van der Brugge and Van Raak 2007).

To illustrate how these approaches address social dynamics of social-ecological change, we compare them using the aquaculture sector, that is, farming fish and other aquatic organisms. Aquaculture is the fastest growing food sector (Bostock et al. 2010), providing economic opportunities through both domestic and export trade (FAO 2012); in doing so, it contributes to global food security and economic growth (e.g., Beveridge et al. 2013). The interaction between the social and environmental dimensions of aquaculture is largely determined by the use of technology and how open the flow of water is between the farm and the surrounding environment. Nevertheless, the rapid growth of the sector over the last few decades has led to both social marginalization and environmental degradation in coastal and 
inland areas (e.g., Stonich 1995, Flaherty and Vandergeest 1998, Islam 2009, Polidoro et al. 2010). The complexity involved in understanding these processes of social, technological, and environmental change in aquaculture therefore provides rich ground for comparing these theoretical approaches.

In this paper, we consider what resilience thinking offers in understanding complex social-ecological change before examining the contribution of agrarian change and sociotechnical transitions theory. We purposefully selected these theories: they both come from strong traditions of understanding change processes in the social sciences and have, to varying degrees, engaged with aquaculture. Other theories of change are more fragmented in the literature, are not socially theoretical, and/ or have not dealt with aquaculture (e.g., Haberl 2001). Rather than suggesting an integrative framework for adding specific social elements into resilience thinking, we argue that these theories may be used in tandem to provide a more robust assessment of the social aspects of social-ecological transition in the aquaculture sector and beyond.

\section{THE AQUACULTURE TRANSITION}

The rapid growth of aquaculture has made it the fastest expanding global production system over the last 40 years (FAO 2012), and it reflects the complexity of agro-food production (Belton and Bush 2014). With respect to fisheries, this expansion also represents a process of animal domestication and a transition from hunting to farming (Natale et al. 2013). Aquaculture produces half of the global fish destined for human consumption, and up to two-thirds of aquatic organisms are produced in China and India; it also contributes to the livelihoods of an estimated 117 million people, or $1.8 \%$ of the global population (see Bostock et al. 2010, Valderrama et al. 2010, World Bank 2012, Beveridge et al. 2013). In Asia, a region responsible for the majority of global production (FAO 2012), rapid change is set against a backdrop of transitional economies in which peasant producers with low to moderate production intensities operate alongside semiintensive quasi-capitalist producers and superintensive industrial farms (Belton et al. 2012). Despite this continuum of production intensities, much of the ownership and labor in Asia remain at the household level, i.e., family-owned and family-operated farms, with fish being produced for domestic, regional, and export consumption (e.g., Loc et al. 2010). Therefore, aquaculture represents a food production system that has both benefits and negative consequences for both human well-being and ecosystem health.

However, questions of who participates in aquaculture production, who drives innovation, and who ultimately benefits reveal highly uneven patterns. The expansion of aquaculture production and consumption is differentiated by species, representing multiple related transitions. Four species groups, penaeid shrimp, pangasius, tilapia, and salmon, dominate global trade, predominantly from the global south to the global north, but represent only $9 \%$ of global production (Belton and Bush 2014). This means that whereas attention to the industrialization of aquaculture production focuses on these export species, the vast majority of expansion, and social and environmental change, is related to species domestically or regionally consumed in the global south with different patterns of intensification and industrialization. A variety of scholars (e.g., Folke and Kautsky
1989, Folke et al. 1998, Kautsky et al. 2000, Edwards et al. 2002, Costa-Pierce 2010) state that understanding these patterns of aquaculture expansion and the social and environmental change they have engendered requires multiscale, integrated frameworks of analysis.

Integrative understandings of aquaculture have predominantly focused on the environmental impacts of aquaculture, which are consistently listed as landscape change, including deforestation and wetland conversion, poor water quality, indiscriminate drug and chemical use, genetic dilution through escapees, use of wild seed, poor fish protein conversion ratios, and intensive energy consumption (see Folke and Kautsky 1992, Naylor et al. 2000, Boyd et al. 2005, Bostock et al. 2010, Klinger and Naylor 2012). In general terms, the degree of these impacts depends on the location and intensity of the production systems, and consequently how open or closed they are to the surrounding environment (Bush et al. 2010, Costa-Pierce 2010). Intensive production with high stocking rates and complete feeding poses a range of disease and environmental risks when open to surrounding ecosystems (Diana et al. 2013). However, closed or "recirculated" intensive aquaculture systems still hold the potential for a greatly reduced environmental footprint over the long term, if these systems prove technically and economically viable (Klinger and Naylor 2012). Given the importance of aquaculture for economic development in regions such as Asia, the tendency toward greater intensification not only raises questions over technological innovation, but also about who will have access, and where and under what economic and political conditions.

A small but growing body of social science research focused on the aquaculture industry has started to address processes of change and transition. For example, Hall's (2004) work on boom crops explores how the development of tropical shrimp aquaculture has been dependent on changing access to and control over key resources such as land and water. The rapid expansion of aquaculture has also led others to look at transitions from agriculture to aquaculture (Ito 2002), and the concomitant inclusion and exclusion of producers in global aquaculture value chains (Phyne and Mansilla 2003, Belton and Little 2008, Islam 2008, Tran et al. 2013). Others have looked at the wider political economy of industry organization, including the effect of private environmental regulation over producers (e.g., Vandergeest 2007, Hatanaka, 2010, Belton et al. 2011a, Bush et al. 2013), and comparative analyses of state support to industry expansion (Phyne 2010). All of these studies focus on social processes that enable and constrain decision making at the farm level, and ultimately affect environmental performance, but are not captured in the bounded social-ecological system ontology of resilience thinking.

The expansion and intensification of aquaculture production, like any other food production sector, also depend on processes of technological innovation. Despite the importance of innovation to the ongoing success of the aquaculture industry (see, e.g., Klinger and Naylor 2012, Diana et al. 2013), it remains poorly understood. Studies have either focused broadly on the political economy of sustainability transitions (Bush and Belton 2011), the epistemological challenges and social consequences of different ways of identifying problems associated with global regulation 
Table 1. Key characteristics and approach to social aspects of change.

\begin{tabular}{|c|c|c|c|c|}
\hline $\begin{array}{l}\text { Change } \\
\text { theories }\end{array}$ & Key characteristics & Approach to social aspects of change & Temporal scale & Major papers \\
\hline Resilience & $\begin{array}{l}\text { Links social and ecological systems, explicitly } \\
\text { emphasizing the dynamic interplay of any } \\
\text { system; views social-ecological systems as } \\
\text { complex, nonlinear, uncertain, and dynamic. } \\
\text { Roots in "new ecology." }\end{array}$ & $\begin{array}{l}\text { Aims to predict regime shifts, threshold } \\
\text { points, and phase transitions so to better } \\
\text { manage transitions. Framework for } \\
\text { understanding nested scales, cross-scale } \\
\text { linkages, and scenario building. }\end{array}$ & Contemporary & $\begin{array}{l}\text { Holling (1973), } \\
\text { Walker et al. } \\
\text { (2004), Folke et } \\
\text { al. (2010) }\end{array}$ \\
\hline $\begin{array}{l}\text { Agrarian } \\
\text { change }\end{array}$ & $\begin{array}{l}\text { Examines agrarian change processes vis-à-vis } \\
\text { understanding shifts in labor and how this } \\
\text { impacts social dynamics. Transitions are seen to } \\
\text { take unexpected turns, with outcomes rarely } \\
\text { being understood from a simple reading of an } \\
\text { event. Takes a relational approach. }\end{array}$ & $\begin{array}{l}\text { Assesses who wins and who loses from } \\
\text { change processes. Provides a thick } \\
\text { analysis of the social dimensions of } \\
\text { transitions; emphasis on social dynamics, } \\
\text { capitalism, and the agrarian class. }\end{array}$ & $\begin{array}{l}\text { Contemporary, } \\
\text { but draws on } \\
\text { historical } \\
\text { processes }\end{array}$ & $\begin{array}{l}\text { Hart et al. (1989), } \\
\text { Bernstein (2001, } \\
\text { 2010), Rigg and } \\
\text { Vandergeest } \\
\text { (2012) }\end{array}$ \\
\hline Transitions & $\begin{array}{l}\text { Conceptualizes transition as an outcome of a } \\
\text { complex interplay between dominant regime and } \\
\text { a set of competing niches, where actors influence } \\
\text { systems and vice versa. Brings in socio-technical } \\
\text { change and emphasizes sustainability. }\end{array}$ & $\begin{array}{l}\text { Focuses on micro-meso-macro interplay } \\
\text { to nudge transitions toward more } \\
\text { sustainable pathways. Technology is } \\
\text { regarded as a heterogeneous element, and } \\
\text { emphasizes the social processes of } \\
\text { transition and change management. }\end{array}$ & $\begin{array}{l}\text { Rapid (e.g., } 10 \\
\text { years), medium } \\
\text { (20-30 years), and } \\
\text { long term change } \\
\text { (50 years) }\end{array}$ & $\begin{array}{l}\text { Rotmans et al. } \\
(2001) \text {, Grin et al. } \\
(2010)\end{array}$ \\
\hline
\end{tabular}

(Konefal and Hatanaka 2011), or the limiting processes of thirdparty auditing (Hatanaka 2013). Only a few studies have attempted to explicitly describe innovation. Those that have describe how successful innovation is dependent on networks of social relations, which facilitate knowledge and sharing practicebased learning (Lebel et al. 2009). Building on this observation, Giap et al. (2010) further explain that while water quality in aquaculture systems is regarded as a technical and regulatory problem, improvements are best understood through a social lens, identifying knowledge arenas in which practical experience, innovation, and specific expertise are brought together.

\section{THEORETICAL CONCEPTUALIZATIONS OF CHANGE}

Given the dynamism evident in the expansion of aquaculture, there is a clear demand for integrated theoretical approaches to explain the drivers and consequences of social and environmental change, especially in vulnerable coastal regions such as Asia. We are interested in how the social dimensions of change are currently incorporated into integrated understanding, and what opportunity there is for more precise explanation. Our theoretical choices represent a selective, focused reading based on areas that we feel warrant further analysis, namely, a more nuanced understanding of human agency, social relations, and the role of technology within the aquaculture sector. We begin by taking a closer look at the social turn (Brown 2013) in resilience thinking itself before examining what agrarian change and socio-technical transition theory offer in terms of understanding selected social dimensions of change processes (see Table 1).

\section{Resilience thinking}

Resilience thinking refers to a cluster of concepts relating to the complex, nonlinear, and mutually enforcing processes within and between social, ecological, and geophysical systems (Holtz et al. 2008). Based on the adaptive cycle, consisting of exploitation, conservation, release, and reorganization (Gunderson and Holling 2002), social resilience and ecological resilience are seen to be coupled, expressing a linkage that emphasizes the dynamic interplay between the human and ecological components of any system (Berkes and Folke 1998, Folke et al. 2005). Such coupling occurs at a local level, between specific sites and the surrounding ecosystems, and at a global level, with feedback occurring across spatial scales (Folke et al. 2010). It is further theorized, based largely on ecology, that both external and internal conditions can influence a system and cause regime shifts (Holling 1973, Garmestani et al. 2009). Resilience theory provides a conceptual framework to assess the relative merits of current versus alternative scenarios, to consider the most favorable stability domain of social-ecological systems, and to reduce risks associated with selected development trajectories (Folke et al. 2010). Proponents argue that by making these options explicit, decisions can be made to better manage transition processes.

Applied to the aquaculture sector, resilience thinking offers a framework to understand different scales, from pond to landscape, that are linked through the flow of water, disease, economic opportunity, and human management (Bush et al. 2010). Indeed, aquaculture provided an empirical basis for earlier resilience thinking (Folke and Kautsky 1989, Berg et al. 1996, Folke et al. 1998, Adger 2000, Kautsky et al. 2000), and has been more recently used to highlight the interrelationship between fish farmers and fish stocks through patterns of resource exploitation (Armitage and Marschke 2013) and wider processes of climate change (Allison et al. 2009, Armitage et al. 2012). Resilience has also been helpful in creating scenarios to assess change trajectories, although resilience is less able to offer an analytic to understand vulnerabilities faced by small producers or the political, social, and economic system structures that constrain or enable opportunities (Miller et al. 2010). The systems-level nature of resilience thinking, which provides a broad heuristic for living in a complex world, limits its utility in concrete decision analysis (Anderies et al. 2013). Even so, scholars are increasingly engaged with resilience thinking and are probing what the term "social" means within social-ecological resilience (e.g., in this Special Feature).

The social turn (Brown 2013) currently under way within resilience thinking has led to a closer examination of the role of 
social learning in enhancing resilience (Olsson et al. 2006), institutional transitions, and adaptive comanagement (Galaz et al. 2008, Plummer and Armitage 2010), with transformation requiring a commitment to novel, innovative approaches to consider alternatives and possible futures (Schoon et al. 2011). Resilient approaches recognize that fundamental change in a social-ecological system will alter everyday practices, relationships, norms, and values across social and ecological scales (Chapin et al. 2010). However, defining desirable adjustments and changes that enhance resilience is fundamentally normative: resilience for some will lead to a loss of resilience for others (Davoudi 2012, Brown 2013, Turner 2013). Resilience has offered key innovations for understanding change management by emphasizing flexible, adaptive institutions (Armitage et al. 2008a, Gelcich et al. 2010). However, it has been less able to deal with the relationship between poverty and power, and how human intervention may counter inequitable adaptive cycles (Davoudi 2012). As Turner (2013) notes, resilience diagnoses are either top down, i.e., society as an organization, negating more inclusive change processes, or laissez-faire, in the sense that competition and creativity among actors provide a natural pathway to resilience.

Although these critiques are not new (e.g., Nadasdy 2007, Leach 2008), scholars have still not found a way to adequately conceptualize social dilemmas within this body of thinking, a point highlighted by the wide range of attempts to incorporate or match social concepts with resilience concepts such as wellbeing (Armitage et al. 2012), transformative agency (Westley et al. 2013), and entrepreneurialism (Moore and Westley 2011). Because resilience cannot incorporate the socially, economically, and politically networked dimensions of globalization, it will continue to face problems in providing explanations of change in rapidly evolving sectors such as aquaculture that require an understanding of regulation, power, and control (Armitage and Johnson 2006, Miller et al. 2010). In short, resilience thinking gives limited attention to the political-economic context in which change occurs and does not adequately address socio-technical processes of innovation that are inherent within the aquaculture sector. Therefore, other theories that deal with these aspects of social-ecological change appear necessary.

\section{Agrarian change}

Agrarian scholars examine change by understanding shifts in control over capital and labor, and by assessing who wins and who loses as a result of such change processes (Bernstein 2004, 2010). The agrarian question concerns (1) social relations and forms of agricultural production that identify transition pathways to (de)industrialization; (2) the position of social divisions of labor in global commodity chains and markets; and (3) how places of production are shaped by the relative strength of agrarian classes in wider political structures, such as the state, and processes, such as social movements (Bernstein and Byres 2001). Classical agrarian scholarship has contextualized decisions for agricultural intensification within a wider set of economic and political relations (Scott 1985), refuting narrow explanations of change that focus only on the benefits of green (and "blue" aquaculture) revolution technologies (Hart 1989). More recent studies focus on land grabbing, food regimes, the links between governments and philanthropic institutions (Patel 2013), and the long-term changes to rural modes of production at multiple scales (Akram-Lodhi and Kay 2010).
Like resilience thinking, agrarian change illustrates processes and events that are nonlinear, uncertain, and complex. Transitions are acknowledged to occur in parallel (De Konick et al. 2012). Applied to the aquaculture sector, agrarian change enables a clearer understanding of the social implications that emerge with intensification in the sector. Examples are the simultaneous processes of depeasantization, with small-holder aquaculture farmers moving into off-farm wage labor, and repeasentization through those returning to aquaculture after a period away (Belton et al. 2012). Moreover, because the agrarian change literature takes both agency and power as main points of departure, thereby providing a "thick" analysis of the social dimensions of transition, particular attention is paid to the structural dimensions and manifestations of power (Duit et al. 2010). For example, Hall et al. (2011) draw attention to how powers of exclusion are exercised in the shrimp industry through a combination of environmental rights, property, and territory. Bernstein and Byres (2001) consider how processes of agricultural modernization, such as mechanization substituting for labor, reflect and stimulate class differentiation and struggle, a process also seen in aquaculture (Stonich 1995, Cruz-Torres, 2000). Agrarian change is therefore highly relevant for the aquaculture sector, particularly given the engagement and divergent outcomes of domestic and export markets, which affect control and access to labor, land, capital, and environmental sustainability.

Agrarian change covers aspects of change that are not well addressed by resilience thinking. In contrast to the systems ontology of resilience, agrarian change takes a relational approach that is less bounded within a particular ecological or social boundary. Studies on the tropical shrimp aquaculture boom in the 1990s, for instance, link local and global processes by examining how market demand led to landscape change and the marginalization of coastal communities (Stonich et al. 1997, Vandergeest et al. 1999, Hall 2009). Agrarian change opens up questions of material power and control over the environment that contrast with the questions of risk, vulnerability, and uncertainty that resilience thinking examines through coupled social-ecological systems. Although resilience concepts are useful in identifying how actors such as fish farmers are subject to wider socio-political structures and environmental processes, these concepts are at risk of depoliticizing processes of change, for example, by neglecting the fundamentally political and cultural construction of economies, by constructing agency only in terms of a capacity to adapt rather than to resist (Evans and Reid 2013), or by reducing the political to the "policing" of adaptation and thereby diverting questions away from power and justice (Welsh 2013).

The strength of resilience is its capacity for systemic comparison, predictive analysis, and the strong inclusion of ecological processes. Indeed, it does this more effectively than agrarian change. The concern of social scientists is the extent to which social insights can be included in a systems-modeling perspective in which cross-scale linkages, social learning, and the need for diversity are effectively used, but not extended in any profound way (Turner 2013). Therefore, agrarian transition is in many ways better equipped to understand the social implications of aquaculture-related transitions, including the social implications of intensification and commercialization, and to address wider questions of how aquaculture differs from agricultural modes of production (cf., Fougères 2008). In doing so, agrarian research 
offers an opportunity not only to provide in-depth empirical cases focused on the situated intricacies of local agency and the social relations of power and control, but also to make wider links to understanding the implications of policy processes for social and ecological change.

\section{Socio-technical transitions theory}

The Dutch school of transition theory focuses on the influence of long-term transformation toward socially and environmentally sustainable societies in response to persistent problems, but with a strong bias toward Western European societies (see Grin et al. 2010). A central way in which it is different from agrarian change and resilience theory is the attention transition theory gives to understanding processes of change in terms of innovation in socio-technical networks. Transition theorists, who have a strongly sociological focus, see technology as a seamless component of social systems, making it attractive to understanding production systems like aquaculture (based on Hughes 1986). In doing so, they offer an additional perspective for understanding how societies can be steered toward normative goals such as sustainability, by analyzing retrospectively how change occurs, complementing agrarian change (see Rigg and Vandergeest 2012), and prospectively through the lens of transition management, complementing resilience thinking (Kemp et al. 2007, Westley et al. 2011).

Technology is regarded as a heterogeneous element in transition theory, including not only hardware but also the mobilization of natural, social, physical, or financial resources, construction of markets, and new regulatory frameworks (Geels and Schot 2010). Encompassing elements of sociological actor network theory (see Latour 2005), transition theorists describe these heterogeneous elements as a set of inherent associations between technical and social aspects, and their use and functional application in specific contexts (Rip and Kemp 1998). In this way, technology is not a solution in itself, but a site for organizing and understanding rapid (e.g., 10 years), medium-term (20-30 years), and long-term (50 years) change (Geels and Schot 2010). The classification of transition horizons and pathways adds a more explicit time element than that provided by either resilience theory or agrarian change, and again draws attention to social processes of innovation and change management, recognizing the tension that exists between spontaneous and managed creativity.

The central organizing framework of this theory is the multilevel perspective (Rip and Kemp 1998, Geels 2002, Geels and Schot 2010). Transition pathways are defined by the conditions of the three levels, small-scale niches, medium-scale regimes, and largescale landscapes, with any shift in pathway explained by innovation at another level, i.e., niches or regimes. As niches emerge and develop, they interact with the dominant regime, which is in turn influenced by the landscape level. Geels and Schot (2010) have created a typology of transition pathways to illustrate the different speeds and trajectories of landscape change and the variability in niche-regime interaction. In doing so, transition theory maintains both constructivist and positivist elements, but of the three theories presented here goes furthest in providing insights into change as a process of socio-technical innovation. Although the main focus has been primarily in a European context, the approach is now being applied in other regions, contexts, and sectors (e.g., Berkhout et al. 2009, Rock et al. 2009), including aquaculture (Lebel et al. 2010, Bush and Belton 2011). Indeed aquaculture is highly amenable to analysis in a multilevel framework because the dynamic growth of the industry has meant that innovation has been a central component of expansion (Lebel et al. 2008). Therefore, transition theory provides rich territory for understanding what kinds of governance arrangements can foster sustainability innovation, either in an entire sector or at the farm level, and how these innovations can emerge as new production regimes.

What is less well attended to in transition theory is the politics of normative policy decisions. For any discussion around the design of pathways for sustainability in the context of aquaculture transitions, a series of normative goals need to be addressed: the "by whom, for whom" kinds of questions. Like resilience, transition theory does not address these processes as well as agrarian change, which is more focused on defining the boundaries around who is in control of what and where, rather than the emergence of innovative sustainability practices. Moreover, the intersection of technology with power dynamics is relatively weak (Lawhon and Murphy 2012), which in aquaculture terms may leave open questions of who controls and who benefits from socio-technical innovations (Hall 2004): Do the less powerful have access to the resources necessary for innovation to occur, and do states and other actors facilitate or take control of these innovations (Ha and Bush 2010)? Applying these questions to aquaculture transitions can reveal the structural dimensions that shape highly politicized debates over, for instance, the ownership of coastal resources (Primavera 2006), the social relations that structure market access (Belton et al. 2011b, Kusumawati et al. 2013, Tran et al. 2013), and the interface of global environmental standards, national legislation, and coastal communities (Vandergeest 2007, Vandergeest and Unno 2012).

Coming full circle in our discussion on the relative merit of these theories to understand social-ecological systems, transition theory is also limited in its capacity to incorporate ecological processes compared with resilience thinking. Although this may be less important for closed aquaculture systems, which aspire to be completely insulated from the surrounding environment, the open systems that dominate production throughout Asia are fundamentally integrated into surrounding landscapes and ecological processes (e.g., Prein 2002, Neori et al. 2007, Berg et al. 2012, Peng et al. 2013). The identification of transition pathways for innovation in socio-technical networks does bring in elements of sustainability, but often where these are related to technology. Ecological processes are placed within the external landscape level. If aquaculture is to be seen as a complex biosocio-technical network (cf., Johnsen et al. 2009), then transition theory suffers some clear weaknesses that can be complemented by the systems ecology focus of resilience theory.

\section{INTEGRATION VERSUS COLLABORATION: EMPHASIZING SOCIAL CHANGE IN AQUACULTURE}

Given the differences between these three theoretical approaches, to what extent might they, individually or collectively, contribute to understanding the social dimensions of transition in aquaculture? Resilience thinking has opened up a range of novel approaches for examining complex processes of change, but its epistemological basis of seeing the social through a "new ecology" lens, as has been widely argued, limits the understanding of social 
processes that influence change and transition, notably social dynamics, agency, and innovation. From their social starting point, agrarian change and transition theory directly address these processes as fundamentally relational. Although agrarian change and transition theorists do refer to sustainability and environment, they do so in an opposite way from resilience: from the social to the ecological. Our comparison adds to recent critiques focusing on the limitations of resilience thinking in dealing with social processes of change within wider socialecological transitions. However, instead of simply deconstructing and reconstructing the social in resilience, we point to the ontological and epistemological boundaries of systems thinking, and in doing so the relative contribution resilience can make visà-vis other social theories of change and transition.

The systems approach of resilience creates a fundamental divide with the two social science theories. Although it is this systems thinking that allows for the designation of causal factors in ecological systems, it limits any reconciliation of social and ecological integration; in some extreme cases, it even conflates cell biology with complex group interactions, thereby stripping humans of agency (e.g., Scheffer and Westley 2007). As Hatt (2012) argues, social systems thinking (e.g., Parsons 1991) has been heavily criticized for its deterministic and static nature, both of which are the antithesis of dynamic complex systems. However, perhaps more fundamentally the question is whether the holistic or "totalizing" aspirations of complex systems create as many problems in understanding processes of social and ecological change as they do benefits. This is not to say that social and ecological processes are unrelated, or that they should be seen as unrelated. Instead it points to what Welsh (2013) labels the unintended consequences of drawing in a range of academic disciplines to the singular ontology of social-ecological systems. We argue that this may happen in at least two different ways.

First, in acknowledging the strengths of resilience thinking, aquaculture, like many production systems, has been successfully understood and manipulated through systems engineering. Therefore, expanding out to environmental problems through the lens of resilience consists of the relatively short, but still highly complicated, step of moving from the production system to the wider ecological system, the first a nested scale within the second. This expansion has been addressed in the literature focused on environmental impact of aquaculture, such as the ecosystembased management approach (e.g., Levin and Lubchenco 2008, Soto et al. 2008), payments for ecosystem services (e.g., Tallis et al. 2008), and life-cycle analysis (e.g., Pelletier et al. 2007, Zhang et al. 2010). These approaches have provided a means of linking economics and the social sciences to resilience, but in a way that reduces social phenomena and processes into system components (cf., Turner 2013). The result is a reification of the system by fitting the social into ecological ways of knowing, rather than, we proffer, a truly integrated understanding of social and ecological change.

Second, a similar process of reification is observed at a theoretical level, whereby social theories of change are co-opted or "naturalized" into resilience thinking (Fig. 1). For instance, the incorporation of social learning in resilience theory has offered new insights, but when made to fit the lexicon of adaptation, it threatens to undermine the very essence of agency; learning is not a given in response to disturbance or change, but is also determined by the social relations that structure an individual's or group's capacity to learn (Armitage et al. 2008b). Likewise, scholars focused on social innovation in resilience theory have focused on networks and institutional entrepreneurs (e.g., Moore and Westley 2011, Westley et al. 2013), with the intention of opening up insights to the adaptive capacity of connected individuals, barriers to change, and strategic opportunities for instigating change. However, in doing so, the authors have attempted to fit social science theories and concepts, ranging from business models to Schumpeter's notion of creative destruction, into the systemic cycle of panarchy (Moore and Westley 2011). Although such conceptual integration is increasingly presented as a way of understanding social-ecological complexity, it is not immediately clear why epistemological integration should be preferred to building bridges between concepts or theories, given the risk of losing the considerable explanatory power already built up in these social sciences theories.

Fig. 1. Naturalization of theories and concepts into resilience thinking.

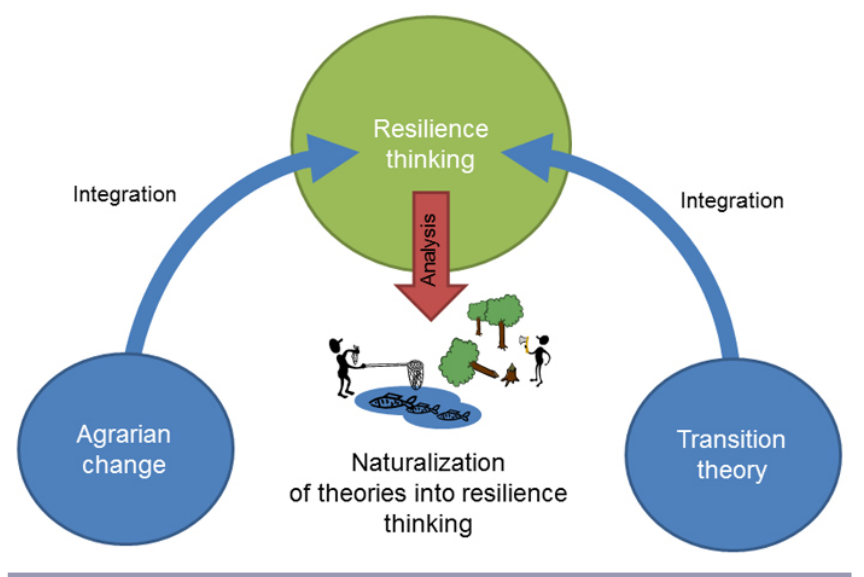

We argue that an improved social and ecological understanding of rapid change in dynamic sectors like aquaculture can be achieved by constructing such bridges between concepts/ disciplines, individuals, and programs (Morse et al. 2007), as opposed to the holism embodied in the integrative systems of resilience thinking (Fig. 2). Understanding how agrarian change and transition theory might complement resilience not only strengthens the position of the social analysis but also avoids the co-option or naturalization of their key concepts into resilience. Doing so might help researchers to avoid the epistemological impasse that follows debates around integrative science, eloquently captured by Wilson (2010:52), who argues that when "discussions are systematic they tend not to be critical, and when they are critical they fail to be systematic," and Davoudi (2012:305), who suggests that in "the social context, a bounded approach soon leads to exclusionary practices." These observations are even more relevant when power, agency, and the politics of control are fundamental to understanding who gets what, when, and how in the case of agrarian change, or who innovates what, when, and how in the case of transition theory. 
Fig. 2. Collaboration between theories in sharing insights with resilience thinking.

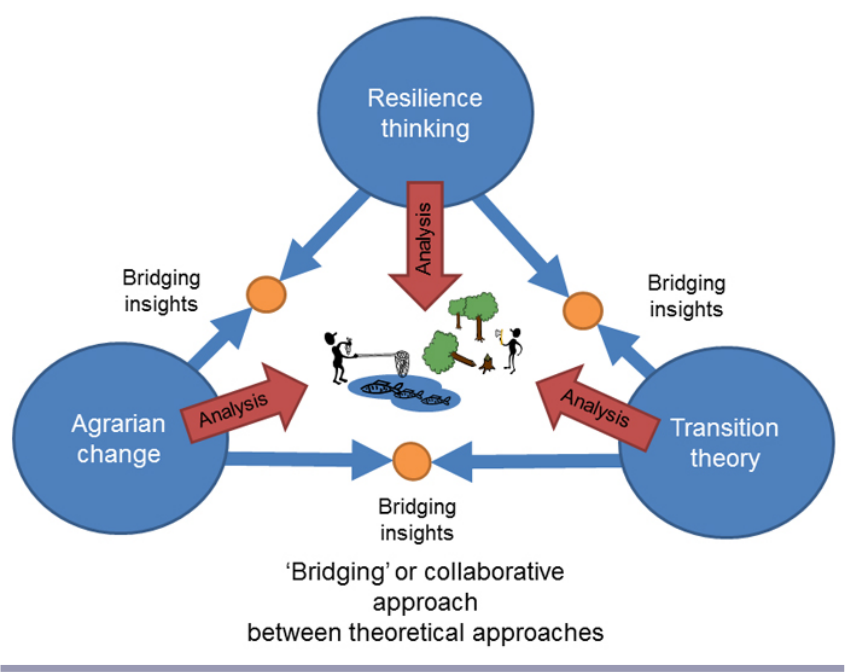

Far from weakening aspirations to understand complex processes of change, we believe such a framework for collaboration can yield valuable insights. Transitions, regardless of their theoretical conception, are multifactor processes influenced by a range of drivers and ever-changing dynamics (Holtz et al. 2008). As argued by Smith and Pickles (1998:2), transitions are in this regard not a one-way process of change from one hegemonic system to another, but rather a "complex reworking of old social relations." No one particular theory will adequately address all change factors, and it may really take a nuanced reading of a situation to determine which theoretical lens or lenses to apply. In addition, just as the systems ontology of resilience thinking constrains how we construct knowledge, so too do the relational and categorical ontologies of agrarian change, defining class, modes, and relations, and transition theory, linking niches, regimes, and landscapes. Each theoretical perspective is therefore "doomed" to form its own perspective on temporal nonlinearity, spatial heterogeneity, global complexity, and structure-agency inconsistency (Wilson 2007). The consequence is that no particular theoretical approach is likely to provide us with adequate analytical power to take into account social-ecological transitions facilitated by social, political, ecological, and technological networks across multiple spatial and temporal scales.

As the importance of aquaculture as a driver of regional economic development and global food security continues to rise, we will be forced to continually consider what implications this sector holds for coastal communities and ecosystems. Critical agrarian questions, including the classic winner and loser questions, remain central to understanding the social drivers and consequences of change. Moreover, methodologies for better complementing the positivist approaches of resilience and transition theory with the qualitative hermeneutics of agrarian change may provide a more nuanced and power-sensitive understanding of transition. Therefore, building conceptual bridges between these areas of scholarship may allow academics and practitioners alike to better understand the interrelated nature of historical transitions, complex social relations, livelihood change, and ecological dynamics. Any further theorization about aquaculture transition should focus on how different constructs can strengthen our understanding of the social dynamics of change, and how these social processes affect wider social-ecological transitions in coastal areas.

Responses to this article can be read online at: http://www.ecologyandsociety.org/issues/responses. $\mathrm{php} / 6677$

\section{Acknowledgments:}

We thank Dr S. Stone-Jovicich and Dr R. Plummer for organizing this Special Feature, and Dr P. Vandergeest, Dr P. Oosterveer, $\mathrm{Dr}$ G. Spaargaren, and Dr D. Armitage for comments on an earlier draft of this paper. M. J. Marschke's research is supported by the Social Science and Humanities Research Council (SSHRC) of Canada. S. R. Bush's research is based on findings from the RESCOPAR programme, funded by the Interdisciplinary Research Fund (INREF) at Wageningen University. Authorship is listed alphabetically.

\section{LITERATURE CITED}

Adger, W. N. 2000. Social and ecological resilience: are they related? Progress in Human Geography 24(3):347-364. http://dx. doi.org/10.1191/030913200701540465

Akram-Lodhi, A. H., and C. Kay. 2010. Surveying the agrarian question (part 2): current debates and beyond. Journal of Peasant Studies 37(2):255-284. http://dx.doi.org/10.1080/03066151003594906

Allison, E. H., A. L. Perry, M.-C. Badjeck, W. N. Adger, K. Brown, D. Conway, A. S. Halls, G. M. Pilling, J. D. Reynolds, N. L. Andrew, and N. K. Dulvy. 2009. Vulnerability of national economies to the impacts of climate change on fisheries. Fish and Fisheries 10(2):173-196. http://dx.doi.org/10.1111/j.1467-2979.2008.00310. $\underline{x}$

Anderies, J. M., C. Folke, B. Walker, and E. Ostrom. 2013. Aligning key concepts for global change policy: robustness, resilience, and sustainability. Ecology and Society 18(2): 8. http:// dx.doi.org/10.5751/ES-05178-180208

Armitage, D., C. Béné, A. T. Charles, D. Johnson, and E. H. Allison. 2012. The interplay of well-being and resilience in applying a social-ecological perspective. Ecology and Society 17 (4): 15. http://dx.doi.org/10.5751/ES-04940-170415

Armitage, D., and D. Johnson. 2006. Can resilience be reconciled with globalization and the increasingly complex conditions of resource degradation in Asia coastal regions? Ecology and Society 11(1): 2 [online] URL: http://www.ecologyandsociety.org/vol11/ iss $1 / \operatorname{art} 2 /$

Armitage, D., and M. Marschke. 2013. Assessing the future of small-scale fishery systems in coastal Vietnam and the implications for policy. Environmental Science and Policy 27:184-194. http://dx.doi.org/10.1016/j.envsci.2012.12.015 
Armitage, D., M. Marschke, and R. Plummer. 2008b. Adaptive co-management and the paradox of learning. Global Environmental Change 18:86-98. http://dx.doi.org/10.1016/j. gloenvcha.2007.07.002

Armitage, D. R., R. Plummer, F. Berkes, R. I. Arthur, A. T. Charles, I. J. Davidson-Hunt, A. P. Diduck, N. C. Doubleday, D. S. Johnson, M. Marschke, P. McConney, E. W. Pinkerton, and E. K. Wollenberg. 2008a. Adaptive co-management for socialecological complexity. Frontiers in Ecology and the Environment 7(2):95-102. http://dx.doi.org/10.1890/070089

Belton, B., and S. R. Bush. 2014. Beyond net deficits: new priorities for an aquacultural geography. Geographical Journal 180(1):3-14. http://dx.doi.org/10.1111/geoj.12035

Belton, B., M. M. Haque, and D. C. Little. 2012. Does size matter? Reassessing the relationship between aquaculture and poverty in Bangladesh. Journal of Development Studies 48(7):904-922. http:// dx.doi.org/10.1080/00220388.2011.638049

Belton, B., M. M. Haque, D. C. Little, and L. X. Sinh. 2011 . Certifying catfish in Vietnam and Bangladesh: who will make the grade and will it matter? Food Policy 36(2):289-299. http://dx.doi. org/10.1016/j.foodpol.2010.11.027

Belton, B., and D. C. Little. 2008. The development of aquaculture in Central Thailand: domestic demand versus export-led production. Journal of Agrarian Change 8(1):123-143. http://dx.doi.org/10.1111/j.1471-0366.2007.00165.x

Belton, B., D. C. Little, and L. X. Sinh. 2011b. The social relations of catfish production in Vietnam. Geoforum 42(5):567-577. http:// dx.doi.org/10.1016/j.geoforum.2011.02.008

Berg, H., C. Berg, and T. T. Nguyen. 2012. Integrated rice-fish farming: safeguarding biodiversity and ecosystem services for sustainable food production in the Mekong Delta. Journal of Sustainable Agriculture 36(8):859-872. http://dx.doi.

org/10.1080/10440046.2012.712090

Berg, H., P. Michélsen, M. Troell, C. Folke, and N. Kautsky. 1996. Managing aquaculture for sustainability in tropical Lake Kariba, Zimbabwe. Ecological Economics 18(2):141-159. http://dx.doi. org/10.1016/0921-8009(96)00018-3

Berkes, F., and C. Folke. 1998. Linking social and ecological systems for resilience and sustainability. Pages 1-26 in F. Berkes and C. Folke, editors. Linking social and ecological systems: management practices and social mechanisms for building resilience. Cambridge University Press, Cambridge, UK.

Berkhout, F., D. Angel, and A. J. Wieczorek. 2009. Asian development pathways and sustainable socio-technical regimes. Technological Forecasting and Social Change 76(2):218-228. http://dx.doi.org/10.1016/j.techfore.2008.03.017

Bernstein, H. 2004. 'Changing before our very eyes': agrarian questions and the politics of land in capitalism today. Journal of Agrarian Change 4(1-2):190-225. http://dx.doi.org/10.1111/ j.1471-0366.2004.00078.x

Bernstein, H. 2010. Introduction: some questions concerning the productive forces. Journal of Agrarian Change 10(3):300-314. http://dx.doi.org/10.1111/j.1471-0366.2010.00272.x
Bernstein, H., and T. J. Byres. 2001. From peasant studies to agrarian change. Journal of Agrarian Change 1(1):1-56.

Beveridge, M. C. M., S. H. Thilsted, M. J. Phillips, M. Metian, M. Troell, and S. J. Hall. 2013. Meeting the food and nutrition needs of the poor: the role of fish and the opportunities and challenges emerging from the rise of aquaculture. Journal of Fish Biology 83(4):1067-1084.

Beymer-Farris, B. A., T. J. Bassett, and I. Bryceson. 2012. Promises and pitfalls of adaptive management in resilience thinking: the lens of political ecology. Pages 283-299 in T. Plieninger and C. Bieling, editors. Resilience in the cultural landscape: understanding and managing change in human-shaped environments. Cambridge University Press, Cambridge, UK. http://dx.doi.org/10.1017/CBO9781139107778.020

Bostock, J., B. Mcandre, R. Richards, K. Jauncey, T. Telfer, K. Lorenzen, D. Little, L. Ross, N. Handisyde, I. Gatward, and R. Corner. 2010. Aquaculture: global status and trends. Philosophical Transactions of the Royal Society B: Biological Sciences 365(1554):2897-2912. http://dx.doi.org/10.1098/rstb.2010.0170

Boyd, C., A. McNevin, J. Clay, and H. M. Johnson. 2005. Certification issues for some common aquaculture species. Reviews in Fisheries Science 13(4):231-279. http://dx.doi. org/10.1080/10641260500326867

Brown, K. 2013. Global environmental change I: a social turn for resilience? Progress in Human Geography 38(1):107-117. http://dx. doi.org/10.1177/0309132513498837

Bush, S. R., and B. Belton. 2011. Out of the factory and into the fish pond: can certification transform Vietnamese Pangasius? Pages 257-290 in G. Spaargaren, A. Loeber, and P. Oosterveer, editors. Food in a sustainable world: transitions in the consumption, retail and production of food. Routledge, London, UK.

Bush, S. R., B. Belton, D. Hall, P. Vandergeest, F. J. Murray, S. Ponte, P. Oosterveer, M. S. Islam, A. P. J. Mol, M. Hatanaka, F. Kruijssen, T. T. T. Ha, D. C. Little, and R. Kusumawati. 2013. Certify sustainable aquaculture? Science 341(6150):1067-1068. http://dx.doi.org/10.1126/science.1237314

Bush, S. R., P. A. M. van Zwieten, L. Visser, H. van Dijk, R. Bosma, W. F. de Boer, and M. Verdegem. 2010. Scenarios for resilient shrimp aquaculture in tropical coastal areas. Ecology and Society 15(2): 15. [online] URL: http://www.ecologyandsociety. org/vol15/iss2/art15/

Chapin, F. S., S. R. Carpenter, G. P. Kofinas, C. Folke, N. Abel, W. C. Clark, P. Olsson, D. M. Stafford Smith, B. Walker, O. R. Young, F. Berkes, R. Biggs, J. M. Grove, R. L. Naylor, E. Pinkerton, W. Steffen, and F. J. Swanson. 2010. Ecosystem stewardship: sustainability strategies for a rapidly changing planet. Trends in Ecology \& Evolution 25(4):241-249. http://dx. doi.org/10.1016/j.tree.2009.10.008

Costa-Pierce, B. A. 2010. Sustainable ecological aquaculture systems: the need for a new social contract for aquaculture development. Marine Technology Society Journal 44(3):88-112. http://dx.doi.org/10.4031/MTSJ.44.3.3

Cote, M., and A. J. Nightingale. 2012. Resilience thinking meets social theory: situating social change in socio-ecological systems 
(SES) research. Progress in Human Geography 36(4):475-489. http://dx.doi.org/10.1177/0309132511425708

Cruz-Torres, M. L. 2000. "Pink gold rush.” Shrimp aquaculture, sustainable development, and the environment in Northwestern Mexico. Journal of Political Ecology: Case Studies in History and Society 7(1):63-90.

Davidson, D. J. 2010. The applicability of the concept of resilience to social systems: some sources of optimism and nagging doubts. Society and Natural Resources 23(12):1135-1149. http://dx.doi. org/10.1080/08941921003652940

Davoudi, S. 2012. Resilience: a bridging concept or a dead end? Planning Theory and Practice 13(2):299-307. http://dx.doi. org/10.1080/14649357.2012.677124

De Konick, R., J. Rigg, and P. Vandergeest. 2012. A half century of agrarian transformation in Southeast Asia 1960-2010. Pages 25-37 in J. Rigg and P. Vandergeest, editors. Revisiting rural places: pathways to poverty and prosperity in Southeast Asia. University of Hawai'i Press, Honolulu, Hawai'i, USA.

Diana, J. S., H. S. Egna, T. Chopin, M. S. Peterson, L. Cao, R. Pomeroy, M. Verdegem, W. T. Slack, M. G. Bondad-Reantaso, and F. Cabello. 2013. Responsible aquaculture in 2050: valuing local conditions and human innovations will be key to success. BioScience 63(4):255-262. http://dx.doi.org/10.1525/bio.2013.63.4.5

Duit, A., V. Galaz, K. Eckerberg, and J. Ebbesson. 2010. Governance, complexity, and resilience. Global Environmental Change. 20(3):363-368. http://dx.doi.org/10.1016/j.gloenvcha.2010.04.006

Edwards, P., D. C. Little, and H. Demaine, editors. 2002. Rural aquaculture. CABI, Oxford, UK.

Evans, B., and J. Reid. 2013. Dangerously exposed: the life and death of the resilient subject. Resilience 1(2):83-98. ttp://dx.doi. org/10.1080/21693293.2013.770703

Flaherty, M., and P. Vandergeest. 1998. 'Low-salt' shrimp aquaculture in Thailand: goodbye coastline, hello Khon Kaen! Environmental Management 22(6):817-830. http://dx.doi.org/10.1007/ $\underline{\mathrm{s} 002679900150}$

Folke, C., S. Carpenter, B. Walker, M. Scheffer, T. Chapin, and J. Rockstrom. 2010. Resilience thinking: integrating resilience, adaptability and transformability. Ecology and Society 15(4): 20 [online] URL: http://www.ecologyandsociety.org/vol15/iss4/ $\underline{\operatorname{art} 20 /}$

Folke, C., T. Hahn, P. Olsson, and J. Norberg. 2005. Adaptive governance of social-ecological systems. Annual Review of Environment and Resources 30:441-473. http://dx.doi.org/10.1146/ annurev.energy.30.050504.144511

Folke, C., and N. Kautsky 1989. The role of ecosystems for a sustainable development of aquaculture. Ambio 18(4):234-243

Folke, C., and N. Kautsky. 1992. Aquaculture with its environment: prospects for sustainability. Ocean \& Coastal Management 17(1):5-24. http://dx.doi.org/10.1016/0964-5691 (92)90059-T

Folke, C., N. Kautsky, H. Berg, A. Jansson, and M. Troell. 1998. The ecological footprint concept for sustainable seafood production: a review. Ecological Applications 8(Supplement
1):563-571. http://dx.doi.org/10.1890/1051-0761(1998)8[S63: TEFCFS]2.0.CO;2

Food and Agriculture Organisation of the United Nations (FAO). 2012. The state of world fisheries and aquaculture. FAO, Rome, Italy.

Fougères, D. 2008. Aquarian capitalism and transition in Indonesia. VDM Verlag Dr. Müller, Saarbrücken, Germany.

Galaz, V., P. Olsson, T. Hahn, C. Folke, and U. Svedin. 2008. The problem of fit among biophysical systems, environmental and resource regimes, and broader governance systems: insights and emerging challenges. Pages 147-182 in O. R. Young, L. A. King, and H. Schröder, editors. Institutions and environmental changeprincipal findings, applications, and research frontiers. MIT Press, Cambridge, Massachusetts, USA. http://dx.doi.org/10.7551/ mitpress/9780262240574.003.0005

Garmestani, A. S., C. R. Allen, and L. Gunderson. 2009. Panarchy: discontinuities reveal similarities in the dynamic system structure of ecological and social systems. Ecology and Society 14(1): 15. http://www.ecologyandsociety.org/vol14/iss1/art15

Geels, F. W. 2002. Technological transitions as evolutionary reconfiguration processes: a multi-level perspective and a casestudy. Research Policy 31(8-9):1257-1274. http://dx.doi. org/10.1016/S0048-7333(02)00062-8

Geels, F. W., and J. Schot. 2010. The dynamics of transitions: a socio-technical perspective. Pages 9-113 in J. Grin, J. Rotmans, and J. Schot, editors. Transitions to sustainable development. Routledge, London, UK.

Gelcich, S., T. P. Hughes, P. Olsson, C. Folke, O. Defeo, M. Fernández, S. Foale, L. H. Gunderson, C. Rodríguez-Sickert, M. Scheffer, R. S. Steneckj, and J. C. Castilla. 2010. Navigating transformations in governance of Chilean marine coastal resources. Proceedings of the National Academy of Sciences of the United States of America 107(39):16794-16799. http://dx.doi. org/10.1073/pnas.1012021107

Giap, D. H., P. Garden, and L. Lebel. 2010. Enabling sustainable shrimp aquaculture: narrowing the gaps between science and policy in Thailand. Pages 123-144 in L. Lebel, S. Lorek, and R. Daniel, editors. Sustainable production consumption systems: knowledge, engagement and practice. Springer, Dordrecht, The Netherlands.

Grin, G., J. Rotmans, J. Schot, F. Geels, and D. Loorbach. 2010. Transitions to sustainable development: new directions in the study of long term transformative change. Routledge, London, UK.

Gunderson, L. H., and C. S. Holling, editors. 2002. Panarchy: understanding transformations in human and natural systems. Island Press, Washington, D.C., USA.

Ha, T. T. T., and S. R. Bush. 2010. Transformations of Vietnamese shrimp aquaculture policy: empirical evidence from $\mathrm{Ca} \mathrm{Mau}$ province, the Mekong Delta. Environment and Planning $C$ : Government and Policy 28(6):1101-1119. http://dx.doi.org/10.1068/ c09194

Haberl, H. 2001. The energetic metabolism of societies part I: accounting concepts. Journal of Industrial Ecology 5(1):11-33. http://dx.doi.org/10.1162/108819801753358481 
Hall, D. 2004. Explaining the diversity of Southeast Asian shrimp aquaculture. Journal of Agrarian Change 4(3):315-335. http://dx. doi.org/10.1111/j.1471-0366.2004.00081.x

Hall, D. 2009. The 2008 World Development Report and the political economy of Southeast Asian agriculture. Journal of Peasant Studies 36(3):603-609. http://dx.doi.org/10.1080/030661$\underline{50903142964}$

Hall, D., P. Hirsch, and T. Murray Li. 2011. Powers of exclusion: land dilemmas in Southeast Asia. National University of Singapore, Singapore.

Hart, G. 1989. Agrarian change in the context of state patronage. Pages 31-49 in G. P. Hart, A. Turton, and B. White, editors. Agrarian transformations: local processes and the state in Southeast Asia. University of California Press, Berkeley, California, USA.

Hart, G. P., Turton, A., and B. White, editors. 1989. Agrarian transformations: local processes and the state in Southeast Asia. University of California Press, Berkeley, California, USA.

Hatanaka, M. 2010. Certification, partnership, and morality in an organic shrimp network: rethinking transnational alternative agrifood networks. World Development 38(5):706-716. http://dx. doi.org/10.1016/j.worlddev.2009.11.001

Hatanaka, M. 2013. Standardized food governance? Reflections on the potential and limitations of chemical-free shrimp. Food Policy 45:138-145. http://dx.doi.org/10.1016/j.foodpol.2013.04.013

Hatt, K. 2012. Social attractors: a proposal to enhance "resilience thinking" about the social. Society \& Natural Resources 26 (1):30-43. http://dx.doi.org/10.1080/08941920.2012.695859

Holling, C. S. 1973. Resilience and stability of ecological systems. Annual Review of Ecology and Systematics 4:1-23. http://dx.doi. org/10.1146/annurev.es.04.110173.000245

Holling, C. S. 2001. Understanding the complexity of economic, ecological, and social systems. Ecosystems 4(5):390-405. http:// dx.doi.org/10.1007/s10021-001-0101-5

Holtz, G., M. Brugnach, and C. Pahl-Wostl. 2008. Specifying "regime"-framework for defining and describing regimes in transition research. Technological Forecasting and Social Change 75(5):623-643. http://dx.doi.org/10.1016/j.techfore.2007.02.010

Hughes, T. P. 1986. The seamless web: technology, science, etcetera, etcetera. Social Studies of Science 16(2):281-292. http:// dx.doi.org/10.1177/0306312786016002004

Islam, M. S. 2008. From pond to plate: towards a twin-driven commodity chain in Bangladesh shrimp aquaculture. Food Policy 33(3):209-223. http://dx.doi.org/10.1016/j.foodpol.2007.10.002

Islam, M. S. 2009. In search of "white gold": environmental and agrarian changes in rural Bangladesh. Society \& Natural Resources 22(1):66-78. http://dx.doi.org/10.1080/08941920801942255

Ito, S. 2002. From rice to prawns: economic transformation and agrarian structure in rural Bangladesh. Journal of Peasant Studies 29(2):47-70. http://dx.doi.org/10.1080/714003949

Johnsen, J. P., P. Holm, P. Sinclair, and D. Bavington. 2009. The cyborgization of the fisheries: on attempts to make fisheries management possible. Maritime Studies 7(2):9-34.
Kautsky, N., P. Rönnbäck, M. Tedengren, and M. Troell. 2000 Ecosystem perspectives on management of disease in shrimp pond farming. Aquaculture. 191(1-3):145-161. http://dx.doi. org/10.1016/S0044-8486(00)00424-5

Kemp, R., D. Loorbach, and J. Rotmans. 2007. Transition management as a model for managing processes of co-evolution towards sustainable development. International Journal of Sustainable Development \& World Ecology 14(1):78-91. http://dx. doi.org/10.1080/13504500709469709

Klinger, D., and R. Naylor. 2012. Searching for solutions in aquaculture: charting a sustainable course. Annual Review of Environment and Resources 37:247-276. http://dx.doi.org/10.1146/ annurev-environ-021111-161531

Konefal, J., and M. Hatanaka. 2011. Enacting third-party certification: a case study of science and politics in organic shrimp certification. Journal of Rural Studies 27(2):125-133. http://dx. doi.org/10.1016/j.jrurstud.2010.12.001

Kusumawati, R., S. R. Bush, and L. E. Visser. 2013. Can patrons be bypassed? Frictions between local and global regulatory networks over shrimp aquaculture in East Kalimantan. Society \& Natural Resources 26(8):898-911. http://dx.doi. org/10.1080/08941920.2012.723305

Latour, B. 2005. Reassembling the social: an introduction to actornetwork-theory. Oxford University Press, Oxford, UK.

Lawhon, M., and J. T. Murphy. 2012. Socio-technical regimes and sustainability transitions: insights from political ecology. Progress in Human Geography 36(3):354-378. http://dx.doi. org/10.1177/0309132511427960

Leach, M., editor. 2008. Re-framing resilience: a symposium report. STEPS Working Paper 13. STEPS Centre, Brighton, UK.

Lebel, L., P. Garden, A. Luers, D. Manuel-Navarrete, and D. H. Giap. 2009. Knowledge and innovation relationships in the shrimp industry in Thailand and Mexico. Proceedings of the National Academy of Sciences of the United States of America. http://dx.doi.org/10.1073/pnas.0900555106

Lebel, L., P. Lebel, P. Garden, D. H. Giap, S. Khrutmuang, and S. Nakayama. 2008. Places, chains, and plates: governing transitions in the shrimp aquaculture production-consumption system. Globalisations 5(2):211-226. http://dx.doi. org/10.1080/14747730802057589

Lebel, L., R. Mungkung, S. H. Gheewala, and P. Lebel. 2010. Innovation cycles, niches and sustainability in the shrimp aquaculture industry in Thailand. Environmental Science \& Policy 13(4):291-302. http://dx.doi.org/10.1016/j.envsci.2010.03.005

Levin, S. A., and J. Lubchenco. 2008. Resilience, robustness, and marine ecosystem-based management. BioScience 58(1):27-32. http://dx.doi.org/10.1641/B580107

Li, T. M. 1999. Compromising power: development, culture and rule in Indonesia. Cultural Anthropology 14(3):295-322. http://dx. doi.org/10.1525/can.1999.14.3.295

Loc, N. T. T., S. R. Bush, L. X. Sinh, and N. T. Khiem. 2010. High and low value fish chains in the Mekong Delta: challenges for livelihoods and governance. Environment, Development and Sustainability 12(6):889-908. http://dx.doi.org/10.1007/s10668-010-9230-3 
Miller, F., H. Osbahr, E. Boyd, F. Thomalla, S. Bharwani, G. Ziervogel, B. Walker, J. Birkmann, S. van der Leeuw, J. Rockström, J. Hinkel, T. Downing, C. Folke, and D. Nelson. 2010. Resilience and vulnerability: complementary or conflicting concepts? Ecology and Society 15(3): 11. [online] URL: http://www. ecologyandsociety.org/vol15/iss3/art11/

Moore, M.-L., and F. Westley. 2011. Surmountable chasms: networks and social innovation for resilient systems. Ecology and Society 16(1): 5. [online] URL: http://www.ecologyandsociety. org/vol16/iss 1/art5/

Moore, M.-L., F. R. Westley, O. Tjornbo, and C. Holroyd. 2012. The loop, the lens, and the lesson: using resilience theory to examine public policy and social innovation. Pages 89-113 in A. Nicholls and A. Murdock, editors. Social innovation: blurring boundaries to reconfigure markets. Palgrave Macmillan, New York, New York, USA.

Morse, W. C., M. Nielsen-Pincus, J. E. Force, and J. Wulfhorst. 2007. Bridges and barriers to developing and conducting interdisciplinary graduate-student team research. Ecology and Society 12(2): 8. [online] URL: http://www.ecologyandsociety. org/vol12/iss2/art8/

Nadasdy, P. 2007. Adaptive co-management and the gospel of resilience. Pages 208-227 in D. Armitage, F. Berkes, and N. Doubleday, editors. Adaptive co-management: collaboration, learning and multi-level governance. UBC Press, Vancouver, British Columbia, Canada.

Natale, F., J. Hofherr, G. Fiore, and J. Virtanen. 2013. Interactions between aquaculture and fisheries. Marine Policy 38:205-213. http://dx.doi.org/10.1016/j.marpol.2012.05.037

Naylor, R. L., R. J. Goldburg, J. H. Primavera, N. Kautsky, M. C. M. Beveridge, J. Clay, C. Folke, J. Lubchenca, H. Mooney, and M. Troell. 2000. Effect of aquaculture on world fish supplies. Nature 405(6790):1017-1024. http://dx.doi.org/10.1038/35016500

Neori, A., M. Troell, T. Chopin, C. Yarish, A. Critchley, and A. H. Buschmann. 2007. The need for a balanced ecosystem approach to blue revolution aquaculture. Environment: Science and Policy for Sustainable Development 49(3):36-43. http://dx.doi. org/10.3200/ENVT.49.3.36-43

O'Brien, K. 2012. Global environmental change III: closing the gap between knowledge and action. Progress in Human Geography 37(4):587-596.

Olsson, P., L. H. Gunderson, S. R. Carpenter, P. Ryan, L. Lebel, C. Folke, and C. S. Holling. 2006. Shooting the rapids: navigating transitions to adaptive governance of social-ecological systems. Ecology and Society 11(1): 18. [online] URL: http://www. ecologyandsociety.org/vol11/iss1/art18/

Parsons, T. 1991. The social system. Second edition. Routledge, London, UK.

Patel, R. 2013. The long green revolution. Journal of Peasant Studies 40(1):1-63. http://dx.doi.org/10.1080/03066150.2012.719224

Pelletier, N. L., N. W. Ayer, P. H. Tyedmers, S. A. Kruse, A. Flysjo, G. Robillard, F. Ziegler, A. J. Scholz, and U. Sonesson. 2007. Impact categories for life cycle assessment research of seafood production systems: review and prospectus. International Journal of Life Cycle Assessment 12(6):414-421.
Peng, Y., G. Chen, S. Li, Y. Liu, and J. C. Pernetta. 2013. Use of degraded coastal wetland in an integrated mangrove-aquaculture system: a case study from the South China Sea. Ocean \& Coastal Management 85(B):209-213. http://dx.doi.org/10.1016/j. ocecoaman.2013.04.008

Phyne, J. 2010. A comparative political economy of rural capitalism: salmon aquaculture in Norway, Chile and Ireland. Acta Sociologica 53(2):160-180. http://dx.doi.org/10.1177/00016$\underline{99310365632}$

Phyne, J., and J. Mansilla. 2003. Forging linkages in the commodity chain: the case of the Chilean salmon farming industry 1987-2001. Sociologia Ruralis 43(2):108-127. http://dx. doi.org/10.1111/1467-9523.00234

Plummer, R., and D. Armitage. 2010. Integrating perspectives on adaptive capacity and environmental governance. Pages 1-19 in D. Armitage and R. Plummer, editors. Adaptive capacity and environmental governance. Springer-Verlag, Berlin, Germany. http://dx.doi.org/10.1007/978-3-642-12194-4 1

Polidoro, B. A., K. E. Carpenter, L. Collins, N. C. Duke, A. M. Ellison, J. C. Ellison, E. J. Farnsworth, E. S. Fernando, K. Kathiresan, N. E. Koedam, S. R. Livingstone, T. Miyagi, G. E. Moore, V. N. Nam, J. E. Ong, J. H. Primavera, S. G. Salmo, III, J. C. Sanciangco, S. Sukardjo, Y. Wang, and J. W. H. Yong. 2010. The loss of species: mangrove extinction risk and geographic areas of global concern. PLoS ONE 5(4):e10095. http://dx.doi. org/10.1371/journal.pone.0010095

Prein, M. 2002. Integration of aquaculture into crop-animal systems in Asia. Agricultural Systems 71(1-2):127-146. http://dx. doi.org/10.1016/S0308-521X(01)00040-3

Primavera, J. H. 2006. Overcoming the impacts of aquaculture on the coastal zone. Ocean \& Coastal Management 49 (9-10):531-545. http://dx.doi.org/10.1016/j.ocecoaman.2006.06.018

Rigg, J. 2001. More than the soil: rural change in Southeast Asia. Pearson Education, Harlow, UK.

Rigg, J., and P. Vandergeest, editors. 2012. Revisiting rural places: pathways to poverty and prosperity in Southeast Asia. University of Hawai'i Press, Honolulu, Hawai'i, USA.

Rip, A., and R. Kemp. 1998. Technological change. Pages 327-399 in S. Rayner and E. L. Malone, editors. Human choice and climate change. Volume 2. Resources and technology. Battelle Press, Columbus, Ohio, USA.

Rock, M., J. T. Murphy, R. Rasiah, P. van Seters, and S. Managi. 2009. A hard slog, not a leap frog: globalisation and sustainability transitions in developing Asia. Technological Forecasting and Social Change 76(2):241-254. http://dx.doi.org/10.1016/j. techfore.2007.11.014

Rotmans, J., R. Kemp, and M. Van Asselt. 2001. More evolution than revolution: transition management in public policy. Foresight 3(1):15-31. http://dx.doi.org/10.1108/14636680110803003

Scheffer, M., and F. R. Westley. 2007. The evolutionary basis of rigidity: locks in cells, minds, and society. Ecology and Society 12 (2): 36 [online] URL: http://www.ecologyandsociety.org/vol12/ iss $2 / \operatorname{art} 36 /$ 
Schoon, M., C. Fabricius, J. M. Anderies, and M. Nelson. 2011. Synthesis: vulnerability, traps, and transformations-long-term perspectives from archaeology. Ecology and Society 16(2): 24. [online] URL: http://www.ecologyandsociety.org/vol16/iss2/ $\underline{\operatorname{art} 24 !}$

Scott, J. C. 1985. Weapons of the weak: everyday forms of peasant resistance. Yale University Press, New Haven, Connecticut, USA.

Smith, A., and J. Pickles. 1998. Introduction: theorizing transition and the political economy of transformation. Pages 1-22 in A. Smith and J. Pickles, editors. Theorizing transition: the political economy of post-communist transformations. Routledge, New York, New York, USA.

Soto, D., J. Aguilar-Manjarrez, C. Brugère, D. Angel, C. Bailey, K. Black, P. Edwards, B. Costa-Pierce, T. Chopin, S. Deudero, S. Freeman, J. Hambrey, N. Hishamunda, D. Knowler, W. Silvert, N. Marba, S. Mathe, R. Norambuena, F. Simard, P. Tett, M. Troell, and A Wainberg. 2008. Applying an ecosystem-based approach to aquaculture: principles, scales and some management measures. Pages 15-35 in D. Soto, J. AguilarManjarrez, and N. Hishamunda, editors. Building an ecosystem approach to aquaculture. FAO/Universitat de les Illes Balears Expert Workshop, 7-11 May 2007, Palma de Mallorca, Spain. FAO fisheries and aquaculture proceedings. No. 14. Food and Agriculture Organisation of the United Nations, Rome, Italy.

Stonich, S. C. 1995. The environmental quality and social justice implications of shrimp mariculture development in Honduras. Human Ecology 23(2):143-168. http://dx.doi.org/10.1007/ BF01191647

Stonich, S. C., J. R. Bort and L. L. Ovares. 1997. Globalization of shrimp mariculture: the impact on social justice and environmental quality in Central America. Society \& Natural Resources 10(2):161-179. http://dx.doi.org/10.1080/08941929709381016

Tallis, H., P. Kareiva, M. Marvier, and A. Chang. 2008. An ecosystem services framework to support both practical conservation and economic development. Proceedings of the National Academy of Sciences of the United States of America 105(28):9457-9464. http://dx.doi.org/10.1073/pnas.0705797105

Tran, N., C. Bailey, N. Wilson, and M. Phillips. 2013. Governance of global value chains in response to food safety and certification standards: the case of shrimp from Vietnam. World Development 45:325-336. http://dx.doi.org/10.1016/j.worlddev.2013.01.025

Turner, M. D. 2013. Political ecology I: an alliance with resilience? Progress in Human Geography 38(4):616-623. http://dx.doi. org/10.1177/0309132513502770

Valderrama, D., N. Hishamunda, and X. Zhou. 2010. Estimating employment in world aquaculture. FAO Aquaculture Newsletter 45:24-25.

Van der Brugge, R., and R. van Raak. 2007. Facing the adaptive management challenge: insights from transition management. Ecology and Society 12(2): 33. [online] URL: http://www. ecologyandsociety.org/vol12/iss2/art33/
Vandergeest, P. 2007. Certification and communities: alternatives for regulating the environmental and social impacts of shrimp farming. World Development 35(7):1152-1171. http://dx.doi. org/10.1016/j.worlddev.2006.12.002

Vandergeest, P., M. Flaherty, and P. Mille. 1999. A political ecology of shrimp aquaculture in Thailand. Rural Sociology 64 (4):573-596. http://dx.doi.org/10.1111/j.1549-0831.1999.tb00379. $\underline{\mathrm{X}}$

Vandergeest, P., and A. Unno. 2012. A new extraterritoriality? Aquaculture certification, sovereignty, and empire. Political Geography 31(6):358-367. http://dx.doi.org/10.1016/j.polgeo.2012.05.005

Walker, B., C. S. Holling, S. R. Carpenter, and A. Kinzig. 2004. Resilience, adaptability and transformability in social-ecological systems. Ecology and Society 9(2): 5. [online] URL: http://www. ecologyandsociety.org/vol9/iss2/art5/

Welsh, M. 2013. Resilience and responsibility: governing uncertainty in a complex world. Geographical Journal 180 (1):15-26. http://dx.doi.org/10.1111/geoj.12012

Westley, F. R., O. Tjornbo, L. Schultz, P. Olsson, C. Folke, B. Crona and Ö. Bodin. 2013. A theory of transformative agency in linked social-ecological systems. Ecology and Society 18(3): 27. http://dx.doi.org/10.5751/ES-05072-180327

Wilson, D. C. 2010. Considering critical dualism: a response to Fikret Berkes. Maritime Anthropological Studies 9(1):51-54.

Wilson, G. A. 2007. Multifunctional agriculture: a transition theory perspective. CABI, Wallingford, UK. http://dx.doi. org/10.1079/9781845932565.0000

World Bank. 2012. World development indicators. World Bank, Washington, D.C., USA.

Zhang, Y., A. Baral, and B. R. Bakshi. 2010. Accounting for ecosystem services in life cycle assessment, part II: toward an ecologically based LCA. Environmental Science \& Technology 44 (7):2624-2631. http://dx.doi.org/10.1021/es900548a 